Pesq. Vet. Bras. 37(10):1139-1145, outubro 2017 DOI: $10.1590 / \mathrm{S} 0100-736 \mathrm{X} 2017001000016$

\author{
Topic of General Interest
}

\title{
Bone marrow stem cell applied in the canine veterinary clinics $^{1}$
}

\author{
Ingrid S. Gomes ${ }^{2}$, Vanessa C. de Oliveira ${ }^{3}$, Alessandra O. Pinheiro ${ }^{2}$, Kelly C.S. \\ Roballo $^{2 *}$, Giuliano S.M. de Araujo ${ }^{2}$, Jessica C. Veronezi ${ }^{2}$, Daniele S. Martins ${ }^{2}$ \\ and Carlos Eduardo Ambrósio ${ }^{2}$
}

\begin{abstract}
Gomes I.S., Oliveira V.C., Pinheiro A.O., Roballo K.C.S., Araujo G.S.M., Veronezi, J.C., Martins D.S. \& Ambrósio C.E. 2017. Bone marrow stem cell applied in the canine veterinary clinics. Pesquisa Veterinária Brasileira 37(10):1139-1145. Department of Veterinary Medicine, Faculty of Animal Science and Food Engineer, University of Sao Paulo, Av. Duque de Caxias Norte, 225, Pirassununga, SP 13635-900, Brazil. E-mail: kellyroballo@gmail.com

Cell therapy represents an old therapeutic practice initiated with the transfusion of whole blood in different clinical situations. There is now a breakthrough in the study of multipotent stem cell therapy because of its functionality in regeneration of tissues, which promotes attention of the scientific community. Bone marrow is one of the main sources of multipotent stem cells, composed by hematopoietic stem cells responsible for the renewal of the cellular components of the blood, and mesenchymal stem cells that aid in the regeneration of tissues. These cells have a strong potential for the treatment of several diseases, due their main characteristics such as high plasticity, capacity for self-renewal and immunomodulation. Although, there are many studies that show good results with the use of cell therapy as a form of treatment for several diseases, some studies still show inconclusive or unsatisfactory results. Therefore, the objective of this study was to review the application of bone marrow stem cells in the canine model since improvements on the knowledge of the technique are necessary to enable its applicability with safety and efficacy.
\end{abstract}

INDEX TERMS: Stem cells, bone marrow, hematopoietic, dogs.

RESUMO.- [Células tronco de medula óssea utilizadas na clínica veterinária canina.] A terapia celular representa uma antiga prática terapêutica iniciada com a transfusão de sangue total em diferentes situações clínicas. Atualmente há um avanço no estudo da terapia com células-tronco mesenquimais por conta de sua funcionalidade na regeneração de tecidos, o que promove uma crescente atenção do meio científico. A medula óssea é uma das principais fontes de células-tronco multipotentes, no qual se encontram as células-tronco hematopoiéticas, responsável pela renovação dos componentes celulares do sangue, e as células-tronco mesenquimais que auxiliam na regeneração de tecidos. Essas células têm um forte potencial para o tratamento de diversas enfermidades, uma vez que possuem como principais

\footnotetext{
${ }^{1}$ Received on December 05, 2016.

Accepted for publication April 25, 2017.

${ }^{2}$ Departamento de Medicina Veterinária, Faculdade de Zootecnia e Tecnologia Alimentar (FZEA), Universidade de São Paulo (USP), Av. Duque de Caxias Norte 255, Pirassununga, SP 13635-900, Brazil. *Corresponding author: kellyroballo@gmail.com

${ }^{3}$ Departamento de Cirurgia, FMVZ-USP, Av. Duque de Caxias Norte 255, Pirassununga, SP 13635-900.
}

características alta plasticidade, capacidade de auto renovação e imunomodulação. Apesar de haver muitos trabalhos que apresentam bons resultados com a utilização da terapia celular como forma de tratamento para diversas enfermidades, alguns estudos ainda demonstram resultados inconclusivos ou não satisfatórios, por isso, objetivou-se com este trabalho revisar a aplicação das células-tronco derivadas da medula óssea no modelo canino uma vez que é necessário melhorias sobre o conhecimento da técnica para que possibilite a sua aplicabilidade com segurança e eficácia.

TERMOS DE INDEXAÇÃO: Células-tronco, medula óssea, hematopoiéticas, cães.

\section{INTRODUCTION}

In the last decade, studies with stem cells have been gaining more space in the veterinary and human medicine (Colomé et al. 2008, Castro-Silva et al. 2010). This fact is related with the stem cell characteristics as undifferentiated state, ability to differentiate into specialized cell lines, self-renew, and self-proliferation (Hamzé et al. 2009). These cells can be classified according to their plasticity such as, totipotent, pluripotent and multipotent, or/and according 
to their origin such as, embryonic or adult (Oliveira 2008, Santos et al. 2013). Additionally, several studies demonstrated, the regenerative function of these cells in damaged tissues (Narazaki \& Cristante 2011, Ryu et al. 2012, Bittencourt et al. 2016, Stolfi et al. 2016).
Adult stem cells can be isolated from various specialized tissues such as adipose tissue, bone marrow, tendon and cartilage (Colomé et al. 2008, Oliveira et al. 2010, Santos et al. 2013). Consequently, the bone marrow stem cell (BMSC), from all the other tissues that have stem cells in
Bone marrow hematopoietic stem cells (BMHC)

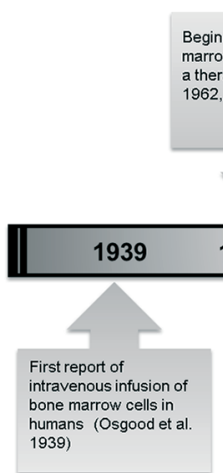

$1950-1970$
Measurement of inducible co-stimulator (ICOS) in dogs after (Sato et al. 2013)
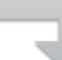

gin of canine bon arrow transplantation as 62, Epstein et al.1967)

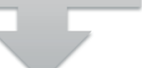

Alteration of distribution of dendritic cells in the cornea and mucosae
after canine BMHCs transplant (Killian et al

2013)
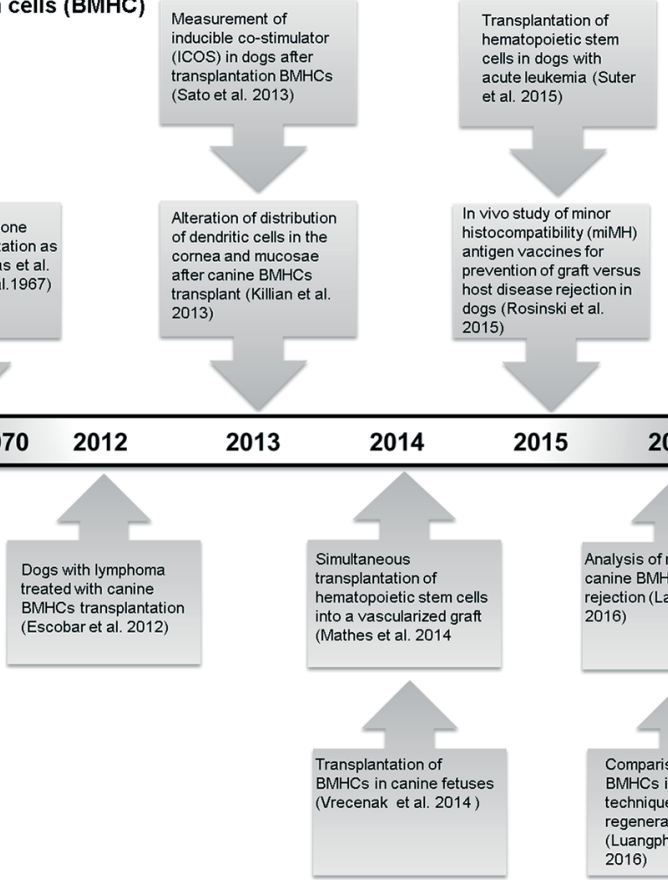

intravenous intra-

BMHCs in

(Lange et al. 2017)

2015

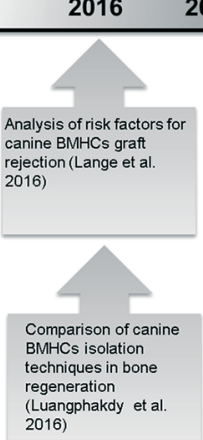

Fig.1. Studies performed in the last years on hematopoietic stem cells from canine bone marrow. (Osgood et al. 1939, Thomas et al. 1962, Epstein et al. 1967, Escobar et al. 2012, Killian et al. 2013, Sato et al. 2013, Mathes et al. 2014, Vrecenak et al. 2014, Rosinski et al. 2015, Suter et al. 2015, Luangphakdy et al. 2016, Lange et al. 2017)

Bone marrow mesenchymal stem cell (BM-MSCs)

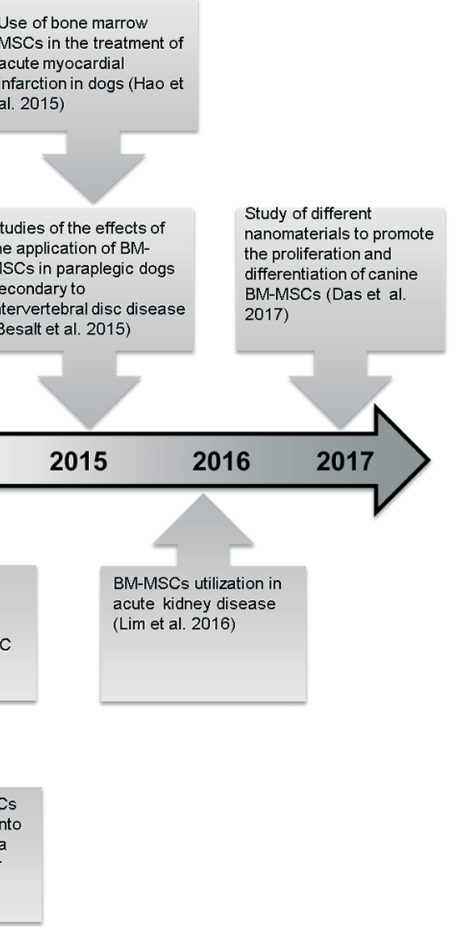

Fig.2. Studies performed in the last years on mesenchymal stem cells from canine bone marrow. (Friedenstein et al. 1974, Tharasanit et al. 2011, Rici et al. 2012, Kim et al. 2013, Hu et al. 2014, Besalt et al. 2015, Guo et al. 2015, Hao et al. 2015, Lim et al. 2016, Das et al. 2017) 
postnatal life, is the most studied, having two lines of stem cells: hematopoietic stem cells (HSC) and mesenchymal stem cells (MSC) (Bittencourt et al. 2006, BydlowskI et al. 2009, Narazaki \& Cristante 2011) (Fig.1 and 2). Furthermore, BMSC is the main source of stem cells, because of its easy isolation, and more than one to six millions of mesenchymal or/and hematopoietic stem cell can be isolated, cultured and applied without problem from one isolation (Oliveira et al. 2010, Ryu et al. 2012, Bittencourt et al. 2016, Stolfi et al. 2016).

In fact, the use of embryos in studies with embryonic stem cells, face several obstacles in relation to ethical issues. Thus, the use of BMSC is a promissory source of stem cell once it did not involve the same philosophical, ethical, and religious issues observed with the use of embryonic stem cells, and the use of hematopoietic and mesenchymal bone marrow cells opened up a new horizon in regenerative medicine (Lo et al. 2003, Braun et al. 2006). Consequently, there is a great enthusiasm about the possibilities of using bone marrow stem cells to treat numerous diseases in several species of animals, especially in the dogs (Suter et al. 2004).

In the veterinary clinic, hematopoietic stem cells can be used for help in the restoration of blood cells and immune cell lineages (Castania 2007, Pereira et al. 2008). On the other hand, mesenchymal stem cell from BMSC can be used in the veterinary clinic for example, in the treatment of bone fractures, spinal cord damage and dermatitis (Pereira et al. 2008, Bydlowski et al. 2009, Ryu et al. 2012, Bittencourt et al. 2016, Stolfi et al. 2016). Thus, this study aimed to carry out a short-review about bone marrow stem cell and check their applicability in the treatment of various diseases in the canine.

\section{BONE MARROW STEM CELLS}

The bone marrow is a viscous material found inside of the bones, with larger source of stem cells in adult animals (Carlson 2009). Bone marrow stem cells are considered multipotent stem cell and can give rise to differentiated cells from the origin tissue (Roobrouck et al. 2008).

The bone marrow stem cell isolation is taken from an intraosseous bone marrow by aspiration (punch). This procedure is suitable when it is desired to obtain cells especially for autologous disease therapy (Muller et al. 2009). The aspiration usually occurs in the epiphysis of long bones, such as the greater trochanter of the femur and greater tuberosity of the humeral bone, iliac crest and trans-iliac area in vivo. In dogs, the region of the iliac crest is widely used due to its location within easy reach (Raskin 1998, Ryu et al. 2012, Bittencourt et al. 2016, Stolfi et al. 2016).

The bone marrow aspirate provides cell suspension that can be handling easily (Muschler et al. 2004). Due to the low extracellular matrix contained in the bone marrow, the soft fragmentation can dissociate hematopoietic stem cells and mesenchymal stem cells. Normally, the HSC and MSC are separated in culture when plated at low-density the bone marrow stem cell, then mesenchymal stem cells will adhere to the plate, and the hematopoietic stem cell will be floating in the culture medium (Bianco et al. 2001, Oliveira et al. 2017).

\section{Hematopoietic stem cells}

Hematopoietic stem cells are from the hematopoietic microenvironment located in the bone marrow cavity from long and plans bones, but other tissues and organs can hosting these cells, such as the spleen, liver, lymph nodes and thymus (Robb et al. 1995, Shivdasanl et al. 1995). Their main feature is the ability of self-renewal, and the potentiality of rise lymphoid and all myeloid cell lineages (Eaves 2015).

Thus, the appropriate stimulus results in the cell differentiation of these precursor cells resulting in future lineages of red blood cells, monocytes, granulocytes, platelets, T-cells and B-cells (Silveira 2000, Castania 2007, Eaves 2015). In dogs, the presence of HSCs have been observed mostly in bone marrow and umbilical cord blood, being used in cell therapy for neoplasia, hematological, metabolic, and immunological diseases (Bruno et al. 2009, Nakage et al. 2009, Ryu et al. 2012, Bittencourt et al. 2016, Stolfi et al. 2016).

The evolution of clinical application of these cells became a reality in 1960 (Ehrlich 1988, Issaragrisil et al. 2006), and one of the first study was realized in children suffering from severe immunodeficiency with advanced leukemia, which received bone marrow transfusions from family donors (Ehrlich 1988). At the same time that emerged a new line of research, which initially used unresponsive patients to any treatment in terminal stages, and has become a therapeutic strategy used for several diseases (Ehrlich 1988, Maluf et al. 2009). In fact, there are limitations for its use such as the choice of the donor which must be healthy and compatible with the receiver, however nowadays, it is one of the most cellular therapy used (Ehrlich 1988, Maluf et al. 2009, Bittencourt et al. 2016, Stolfi et al. 2016).

According to the progenitor stem cells donor, HSC transplantation may be divided into three types: allogeneic, syngeneic and allogeneic (Azevedo \& Ribeiro 2000). The allogeneic refers when the stem cells are derived from a genetically distinct donor with HLA gene compatible or not, thus, this type of transplant becomes very dangerous and can presents complications related to immunological reactions between recipient and donor (Brandão et al. 2008). Synergic transplantation occurs between identical twin siblings, where the antigenic identity between donor and recipient is absolute and therefore there is no immunological complication. The autologous is when the progenitor cells used are the patient's own (Ehrlich 1988, Gupta et al. 2009). Furthermore, this last type of transplant generates a lower risk than the halogen, because there is no type of immune response between recipient and donor, but with a higher relapse rate (Ehrlich 1988, Gupta et al. 2009).

\section{Mesenchymal stem cell}

Mesenchymal stem cells are defined as a population of somatic stem cells present in small amounts in perivascular regions of adult tissues, such as bone marrow, adipose tissue, periosteum, and parenchymal organs. Bone marrow mesenchymal stem cell also are known as bone marrow stromal cells or multipotent stromal-mesenchymal cells, receiving these denominations because they can be obtai- 
ned through the bone marrow stroma and they are able to differentiate into several mesoderm and non-mesodermal cell lines (Bydlowski et al. 2009, Tharasanit et al. 2011).

MSCs have characteristics of high renewal power and differentiation in several cell lineages, the cell lines of the mesoderm that MSCs can originate are adipocytes, osteocytes, chondrocytes, and connective stroma cells, which demonstrates their high plasticity (Pereira et al. 2008, Nakage et al. 2009, Castro-Silva et al. 2010, Monteiro et al. 2010, Tharasanit et al. 2011). Thus, the MSCs have been use to recover damaged organs and tissues by introducing them after a differentiation induction into the compromised places and restoring the lost function (Narazaki \& Cristante 2011).

According to the International Society for Cellular Therapy, there are three minimum requirements for a cell population to be considered as MSCs. The first, MSCs are isolated from a population of mononuclear cells based on their selective adherence to the plastic surface, whereas the hematopoietic cells do not adhere. Second, the cells need to be positive for CD105, CD73 and CD90, and negative for CD34, CD45, CD14, CD11b, CD79, or CD19 and HLA-DR. Finally, the third, the cells need to differentiate between osteoblasts, chondroblasts and adipocytes. Additionally, studies confirm that in culture and conditions for culturing, MSCs exhibit fibroblastoid morphology (Casteilla et al. 2011, Tharasanit et al. 2011, Mançanares et al. 2015).

Furthermore, such as stem cell characteristics and the potential benefits bring a new possibility in the treatment of congenital, degenerative, vascular, traumatic, and iatrogenic conditions (Hamzé et al. 2009, Oliveira et al. 2010). Thus, this cellular type is being widely used in researches because they do not present ethical barriers due to the ease of obtaining them and still to be used in autologous transplants, less probability of immunological rejection and the need of cellular inventory, since they are apparently inexhaustible (Castro-Silva et al. 2010). Nevertheless, as previous cited, MSCs have the potential to undergo to differentiation into cells of the mesodermal lineage, such as bone, fat and cartilage, and have the potential to differentiate into cells of the endodermal and ectodermal linage (Nakage et al. 2009, Pinto Filho et al. 2013).

\section{APPLICATION OF BONE MARROW STEM CELLS}

Studies for the use of bone marrow stem cells in the veterinary medicine are being started and applied widely. The canine is an animal model commonly used for studies, which provide preclinical information to the human research (Kolf et al. 2007, Lange et al. 2016). The use of stem cells is being explored in the areas of ophthalmology, cardiology, orthopedics, neurology, among others (Oliveira 2008, Ryu et al. 2012).

In the veterinary medicine there are the use of these cells in the assisted reproduction, for the preservation of endangered species, and are also used to generate transgenic animals and production of biomedical models, and studies aiming the cell transplantation as an alternative for the treatment of pathologies in dogs (Kolf et al. 2007). For example, studies with cell transfusion of CD6 periphe- ral blood stem cells in dogs for 6 days showed an attempt of animal's immune tolerance, and it was observed a significant improvement non-graft and chimerism of the cells (Zorn et al. 2011).

On the other hand, Dale \& Graw (1974) reported that after bone marrow cell transplantation treatment in a gray collie dog that had clinical neutropenia, the patient had normal granulocytopoise. In addition, Jung et al. (2009)'s study compared the therapeutic effects of autologous and allogenic bone marrow MSCs in dogs with spinal cord injury, using thirty dogs, where mesenchymal stem cells were transplanted subarachnoid in the lumbar spinal cord after 7 days of spinal cord injury. It was reported that in both the autologous transplantation and the allogeneic transplant groups, the dogs showed improvement in the neurological signs of the pelvic limbs and increased mRNA expression for neurotrophic factors during the 1st and 4th week after transplantation. However, the rate of distribution of bone marrow MSCs in wound injury in the allogeneic transfusion group was significantly reduced at 4 weeks post-transplant, concluding that autologous transplantation had a better outcome than allogeneic transplantation, although both presented improvements significant.

In a study carried out by Tharasanit et al. (2011) in order to isolate, identify the differentiation capacity of mesenchymal cells in dogs, bone marrow cells were aspirated, cultured and the have expression of the CD34, CD44 and CD90 markers was assessed by flow cytometry. Additionally, it was possible to observe that bone marrow MSCs had the ability to differentiate into different mesodermal lines.

In orthopedics, Ribeiro (2009) studied the repair in defects of bone dehiscence using implants of bone marrow cells by autogenous transplantation alone or in combination with the technique of guided bone regeneration in dogs. Bone marrow was obtained from the iliac crest of eight adult male beagle dogs, where bone marrow MSCs were isolated, cultured in vitro and phenotypically characterized with respect to their osteogenic properties. In the results the bone marrow stem cells isolated promoted good results in relation to the bone formation within the threads of the implant. Furthermore, Rici et al. (2012) conducted a study about proliferation effects of canine bone marrow mesenchymal stem cells and rhBMP-2 treated osteosarcoma cells. It was possible to observe that the treatment of osteosarcoma using canine MSC with rhBMP-2 induced a decrease in P53 marker expression, a decrease in Ki67 expression, significant increase in phosphorylated apoptosis of caspase-3, and expression of pro-apoptotic Bax protein, in addition to a decrease in expression of the anti-apoptotic protein of Bcl-2.

In cardiology, in the Nakamuta (2008) study, it was possible to perceive the transplants performed up to 24 hours after the ischemia presented a certain reestablishment of intramyocardial cardiac cells, leading to an improvement in the cardiac performance. In dermatology, a research carried out with a Beagle breed realized by Kim et al. (2013) evaluated whether BM-MSCs from allogeneic transplantation could accelerate wound healing and/or alleviate cutaneous inflammation. In addition, it was observed that 
there was an increase in collagen in wounds treated with mesenchymal cells when compared to the control group, with increased cell proliferation and reduction in post- inflammatory cytokines.

In a study carried out by Togonoli et al. (2009) where16 dogs were submitted to experimental corneal ulcer with filter paper embedded in sodium hydroxide $(\mathrm{NaOH})$, had a subconjunctival transplantation of BM-MSCs, previously marked with nanocrystals and after 15 days evaluated by immunofluorescence and histopathology. It was possible to observe that the mesenchymal cells were fixed in the injured region and did not undergo chemotaxis. However, although they diminished the inflammation, they did not help the corneal healing process in the short term.

Additionally, Krause et al. (1994), McSweeney et al. (1998), Ratajczak et al. (1998) and Bruno et al. (1999) realized studies with canine hematopoietic stem cells, because of its similarity to hematopoietic stem cells from humans and mice. They demonstrate that these cells have the capacity of hematopoietic reconstitution and plasticity. The canine model is used in several scientific and therapeutic proposals that provide preclinical information to the human research.

\section{CONCLUSIONS}

Cell therapy has been very successful as a treatment option for various diseases and could revolutionize veterinary medicine in the future.

Bone marrow stem cells are promising in the treatment of many hematologic and tissue pathology, but there are still some difficulties to be faced in relation to the handling, differentiation and application of these cells in vivo, but there according to the studies there are great expectations in the resolution of several diseases in the future.

Acknowledgements.- The authors are grateful to Foundation for Research Support of the Sao Paulo State (FAPESP), for financial support (Process no 2015/17897-9).

Conflict of interest statement.- The authors have no competing interests.

\section{REFERENCES}

Azevedo W. \& Ribeiro M.C.C. 2000. Fontes de células-tronco hematopoéticas para transplantes. Med. Ribeirão Preto 33:381-389.

Besalti O., Can P., Akpinar E., Aktas Z., Elcin A.E. \& Elcin Y.M. 2015. Intraspinal transplantation of autologous neurogenically-induced bone marrow-derived mesenchymal stem cells in the treatment of paraplegic dogs without deep pain perception secondary to intervertebral disk disease. Turk Neurosurg. 25(4):625-632.

Bianco P., Riminucci M., Gronthos S. \& Robey P.G. 2001. Bone marrow stromal stem cells: nature, biology, and potential applications. Stem Cells 19:180-192

Bittencourt R.A.C., Pereira S.L.F., Murador P., Oliveira A.P.E. \& Deffune E. 2006. Isolamento de células-tronco mesenquimais da medula óssea. Acta Ortop. Bras. 14(1):22-24.

Bittencourt M.K., Barros M.A., Martins J.F., Vasconcellos J.P., Morais B.P., Pompeia C., Bittencourt M.D., Evangelho K.D., Kerkis I. \& Wenceslau C.V. 2016. Allogeneic Mesenchymal Stem Cell Transplantation in Dogs With Keratoconjunctivitis Sicca. Cell Med. 8(3):63-77.

Brandão A.P., Brandão A.A., De Magalhães M.E. \& Pozzan R. 2008. Management of metabolic syndrome in young population. Am. J. Ther. 15(4):356-361.
BraunI A.C. \& PrankeI P. 2006. Potencialidades da terapia com células-tronco na regeneração hepática. Revta Inst. Adolfo Lutz 65(3):146-156.

Bruno B., Nash R.A., Wallace P.M., Gass M.J., Thompson J., Storb R. \& McSweeney P.A. 1999. CD34+ selected bone marrow grafts are radioprotective and establish mixed chimerism in dogs given high dose total body irradiation. Transplantation 68(3):338-344.

Bruno J.B., Matos M.H.T., Chaves R.V., Celestino J.J.H., Saraiva M.V.A., Lima-Verde I.B. Araujo V.R. \& Figueiredo J.R. 2009. Angiogenic factors and follicular development. Anim. Reprod. 6(2):371-379.

Bydlowski S.P., Debes A.A., Maselli L.M.F. \& Janz F.L. 2009. Características biológicas das células-tronco mesenquimais. Revta Bras. Hematol. Hemoter. 31:25-35.

Carlson B.M. 2009. Stem Cell Anthology: stem cell biology, tissue engineering cloning, regenerative medicine and biology. Academic Press Elsevier. $422 \mathrm{p}$.

Castania V.A. 2007. Enxerto cortico esponjoso homógeno processado quimicamente, esterilizado em óxido de etileno e embebido em medula óssea autógena Thesis, Faculdade de Medicina de Ribeirão Preto, Universidade de São Paulo, Ribeirão Preto, SP.

Casteilla L., Benard V.P., Laharrague P. \& Cousin B. 2011. Adipose-derived stromal cells: their identity and uses in clinical trials, an update. World J. Stem Cells 3(4):25-33.

Castro-Silva I.I., Coutinho L.A.C.R. \& Granjeiro J.M. 2010. Revisão sistemática sobre o uso de células-tronco mesenquimais em terapias de perdas ósseas. Innov. Impl. J. 5(3):29-34.

Colomé L.M., Gomes C., Crosignani N., Paz A.H., Lugo A.A., Guimarães K. M., Foerstrow L.P., Tessari J.P., Colomé L.M., Graça D.L., Meurer L., Passos E.P., Pippi N.L., Contesini E.A. \& Lima E.O.C. 2008. Utilização de células-tronco autólogas de medula óssea na regeneração do nervo tibial de coelhos mediante técnica de tubulização com prótese de silicone. Ciência Rural 38(9):2529-2534.

Dale C.D. \& Graw G.R. 1974. Transplantation of allogeneic bone marrow in canine cyclic neutropenia. Science 183(4120):83-84.

Das K., Mili B., Madhusoodan A.P., Saxena A.C., Kumar A., Singh P., Verma M.R., Sarkar M. \& Bag S. 2017. Proliferation of canine bone marrow derived mesenchymal stem cells on different nanomaterial based thin film scaffolds. Tissue Cell; doi: http://dx.doi.org/10.1016/j.tice.2017.02.002

Eaves C.J. 2015. Hematopoietic stem cells: concepts, definitions, and the new reality. Blood 125:2605-2613; doi: https://doi.org/10.1182/ blood-2014-12-570200

Ehrlich P. 1988. Über in dem Fall von Anämie mit Bemerkungen über regenerative Veränderungen des Knochenmarks. Charite-Annalen 13:301309.

Epstein R.B., Bryant J. \& Thomas E.D. 1967. Cytogenetic demonstration of permanent tolerance in adult outbred dogs. Transplantation 5:267-272.

Escobar C., Grindem C., Neel J.A. \& Suter S.E. 2012. Hematologic changes after total body irradiation and autologous transplantation of hematopoietic peripheral blood progenitor cells in dogs with lymphoma. Vet. Pathol. 49(2):341-343.

Friedenstein A.J., Chailakhyan R.K., Latsinik N.V., Panasyuk A.F. \& Keiliss-Borok I.V. 1974. Stromal cells responsible for transferring the microenvironment of the hemopoietic tissues. Cloning in vitro and retransplantation in vivo. Transplantation 17:331-340.

Guo P., Zeng J.J. \& Zhou N. 2015. A novel experimental study on the fabrication and biological characteristics of canine bone marrow mesenchymal stem cells sheet using vitamin C. Scanning 37(1):42-48.

Gupta P., Khurana N., Singh T., Gupta D. \& Dhingra K.K. 2009. Bone marrow angiogenesis in aplastic anemia--a study of CD 34 and VEGF expression in bone marrow biopsies. Hematology 1:16-21.

Hamzé A.L., Pacheco A.M., Bérgamo M., Júnior O.P.S., Dotta S.C.N., Sacco S.R. \& Filadelpho A.L. 2009. Células-tronco na Medicina Veterinária. Revta Cient. Eletr. Med. Vet. 7(12):1-4.

Hao L., Hao J., Fang W., Han C., Zhang K. \& Wang X. 2015. Dual isotope simultaneous imaging to evaluate the effects of intracoronary bone marrow-derived mesenchymal stem cells on perfusion and metabolism in canines with acute myocardial infarction. Biomed. Rep. 3(4): 447-452. 
Hu Y.C., Liu X., Shen J.J., He J.C. \& Chen Q.E. 2014. Experimental study of canine bone marrow mesenchymal stem cells combined with calcium phosphate cement for repair of mandibular bone defects in Beagle dogs. Shanghai Kou Qiang Yi Xue 23(4):402-408.

Issaragrisil S., Kaufman D.W., Anderson T., Chansung K., Leaverton P.E., Shapiro S. \& Young N.S. 2006. The epidemiology of aplastic anemia in Thailand. Blood 4:1299-1307.

Jung D.I., Ha J., Kang B.T., Kim J.W., Quan F.S., Lee J.H., Woo E.J. \& Park H.M. 2009. A comparison of autologous and allogenic bone marrow-derived mesenchymal stem cell transplantation in canine spinal cord injury. Jour. of the Neurol. Sci. 285(1/2):67-77.

Kim J.K., Lee J.H., Lyoo Y.S., Jung D.I. \& Park H.M. 2013. The effects of topical mesenchymal stem cell transplantation in canine experimental cutaneous wounds. Vet. Dermatol. 24(2):242-253.

Killian D., Reichard M., Knueppel A., Lange S., Sekora A., Knuebel G., Murua E.H., Guthoff R., Stachs O. \& Junghanss C. 2013. Distribution changes of epithelial dendritic cells in canine cornea and mucous membranes related to hematopoietic stem cell transplantation. In Vivo 27(6):761-771.

Kolf C.M., Cho E. \& Tuan R.S. 2007. Mesenchymal stromal cells: biology of adult mesenchymal stem cells: regulation of niche, self-renewal and differentiation. Arthritis Res. Ther. 9(1):204.

Krause D.S., Ito T., Fackler M.J., Smith O.M., Colector M.I., Sharkis S.J. \& Maio W.S. 1994. Characterization of murine CD34, a marker for hematopoietic progenitor and stem cells. Blood 84(3):691-701.

Lange S., Steder A., Vidro A., Killian D., Wittmann S., Machka C., Werner J., Schäfer S., Roolf C. \& Junghanss C. 2016. Low radiation dose and low cell dose increase the risk of graft rejection in a canine hematopoietic stem cell transplantation model. Biol. Blood Marrow Transplant. 22(4):637643.

Lange S., Steder A., Killian D., Knuebel G., Sekora A., Vogel H., Lindner I., Dunkelmann S., Prall F., Escobar H.M., Freund M. \& Junghanss C. 2017. Engraftment efficiency after intra-bone marrow versus intravenous transplantation of bone marrow cells in a canine nonmyeloablative dog leukocyte antigen-identical transplantation model. Biol. Blood Marrow Transplant. 23(2):247-254.

Lim C.Y., Han J.I., Kim S.G., Lee C.M. \& Parque H.M. 2016. Evaluation of autologous bone marrow-derived mesenchymal stem cells on renal regeneration after experimentally induced acute kidney injury in dogs. Am. J. Vet. Res. 77(4):403.

Lo K.C., Chuang W.W. \& Lamb D.J. 2003. Stem cell research: the facts, the myths and the promises. J. Urology 170(6):2453-2458.

Luangphakdy V., Boehm C., Pan H., Herrick J., Zaveri P. \& Muschler G.F. 2016. Assessment of methods for rapid intraoperative concentration and selection of marrow-derived connective tissue progenitors for bone regeneration using the canine femoral multidefect model. Tissue Eng. A 22(1/2):17-30.

Maluf E., Hamerschlak N., Cavalcanti A.B., Júnior A.A., Eluf-Neto J., Falcão R.P., Lorand-Metze I.G., Goldenberg D., Santana C.L., Rodrigues D.O., Passos L.N., Rosenfeld L.G., Pitta M., Loggetto S., Ribeiro A.A., Velloso E.D., Kondo A.T., Coelho E.O., Pintão M.C., de Souza H.M., Borbolla J.R. \& Pasquini R. 2009. Incidence and risk factors of aplastic anemia in Latin American countries: the LATIN case-control study. Haematologica 9:1220-1226.

Mançanares C.A., Oliveira V.C., Oliveira L.J., Carvalho A.F., Sampaio R.V., Mançanares A.C., Souza A.F., Perecin F., Meirelles F.V., Miglino M.A. \& Ambrosio C.E. 2015. Isolation and characterization of masenchymal stem cells from the yplk sacs of bovine embryos. Theriogenol. 84(6):887-898.

Mathes D.W., Chang J., Hwang B., Graves S.S., Storer B.E., Butts-Miwongtum T., Venda G.E. \& Storb R. 2014. Simultaneous transplantation of hematopoietic stem cells and a vascularized composite allograft leads to tolerance. Transplantatin 98(2):131-138.

Mcsweeney P.A., Rouleau K.A., Wallace P.M., Bruno B., Andrews R.G., Krizanac-Bengez L., Sandmaier B.M., Storb R., Wayner E. \& Nash R.A. 1998. Characterization of monoclonal antibodies that recognize canine CD34. Blood 91(6):1977-1986.

Monteiro B.S., Argolo Neto N.M. \& Del Carlo J. 2010. Células-tronco mesenquimais. Ciência Rural 40(1):238-245.
Muller D.C.M., Pippi N.L., Basso P.C., Olsson D.C., Santos Junior E.B. \& Guerra A.C.O. 2009. Técnicas e sítios de coleta de medula óssea em cães e gatos. Ciência Rural 39(7):2243-2251.

Muschler G.F., Nakamoto C. \& Griffith L.G. 2004. Engineering principles of clinical cell-based tissue engineering. J. Bone Joint Surg. A 86:15411558.

Nakage A.P.M., Santana A.E., Cápua M.L.B. \& Godoy A.V. 2009. Quantificação de células CD34+ do sangue do cordão umbilical de cães. Ciência Rural 39(2):434-441.

Nakamuta J.S. 2008. Terapia celular para isquemia cardíaca: efeitos da via de administração, do tempo pós-lesão e do uso de bipolimero para rentenção das células e função miorcárdica. Tese de Doutorado, Programa de Pós-Graduação, Faculdade de Medicina, São Paulo.

Narazaki D.J. \& Cristante A.F. 2011. Avanços no uso de células-tronco em ortopedia. Revta Bras. Ortoped. 46(4):359-367.

Oliveira G.K. 2008. Células-tronco mononucleares autólogas na cicatrização de defeitos tibiais agudos experimentais de cão. Tese de Doutorado, Universidade Federal de Santa Maria, Santa Maria, RS.

Oliveira V.C., Mançanares C.A., Oliveira L.J., Gonçalves N.J., Miglino M.A., Perecin F., Meirelles F.V., Piedrahita J. \& Ambrósio C.E. 2017. Characterization of putative haematopoietic cells from bovine yolk sac. J. Tissue Eng. Regen. Med. 11(4):1132-1140.

Oliveira G.K., Raiser A.G., Olsson D., Salbego F.Z., Martins D.B., Dezengrine R., Santos Junior E.B., Rappeti J., Trindade L.B., Tognoli G.K., Pippi N.L. \& Sausen L. 2010. Células-tronco mononucleares e proteína óssea morfogenética na cicatrização de defeitos tibiais experimentalmente induzidos em cães. Arq. Bras. Med. Vet. Zootec. 62(1):72-79.

Osgood E.E., Riddle M.C. \& Mathews T.J. 1939. Aplastic anemia treated with daily transfusions and intravenous marrow: case report. Ann. Intern. Med. 13:357-367.

Pereira I.S.O., Pontes P., Eça L.P., Ferreira A.T., Mazzetti P.M.V., Silva L. \& Souza F.C. 2008. Protocolo piloto de separação e quantificação de células tronco de tecido adiposo de coelhos para posterior uso em laringe. Acta ORL 26(3):11-16.

Pinto Filho S.T.L., Treichel T.L.E., Aramburú Junior J.S., Rosa M.B., Dalmolin F., Brun M.V., Krause A. \& Pippi N.L. 2013. Células-Tronco mesenquimais adultas: Características e aplicações experimentais em animais. Vet. Zootec. 20:49-59.

Raskin R. 1998. Medula óssea, p.1135-1142. In: Slatter D. (Ed.), Manual de Cirurgia de Pequenos Animais. Manole, São Paulo.

Ratajczak M.Z., Pletcher C.H., Marlicz W., Machalinski B., Moore J., Wasik M., Ratajczak J. \& Gewirtz A.M. 1998. CD34+, Kit $^{+}$, Rhodamine $123^{\text {low }}$ phenotype identifies a marrow cell population highly enriched for human hematopoietic stem cells. Leukemia 12:942-950.

Ribeiro F.V. 2009. Avaliação da regeneração óssea em defeitos peri-implantares de deiscência tratados com uma abordagem combinada associando células derivadas da medula óssea e regeneração óssea guiada. 60 f. Tese de Doutorado, Faculdade de Odontologia de Piracicaba, Universidade Estadual de Campinas, SP.

Rici R.E., Alcantara D., Fratini P., Wenceslau C.V., Ambrosio C.E., Miglino M.A. \& Maria D.A. 2012. Mesenchymal stem cells with rhBMP-2 inhibits the growth of canine osteosarcoma cells. BMC Vet. Res. 8:17.

Robb L., Lyons I., Li R., Hartley L., Köntgen F., Harvey R.P., Metcalf D. \& Begley C.G. 1995. Absence of yolk sac hematopoesis from mice with a targeted disruption of thesclgene. Proc. Natl Acad. Sci. USA 92:7075-7079.

Roobrouck V.D., Ulloa-Montoya F. \& Verfaillie C.M. 2008. Self-renewal and differentiation capacity of young and aged stem cells. Exp. Cell Res. 314:1937-1944.

Rosinski S.L., Stone B., Graves S.S., Fuller D.H., De Rosa S.C., Spies G.A., Mize G.J., Fuller J.T. \& Storb R. 2015. Development of a minor histocompatibility antigen vaccine regimen in the canine model of hematopoietic cell transplantation. Transplantation 99(10):2083-2094.

Ryu H.H., Kang B.J., Park S.S., Kim Y., Sung G.J., Woo H.M., Kim W.H. \& Kweon O.K. 2012. Comparison of mesenchymal stem cells derived from fat, bone marrow, Wharton's jelly, and umbilical cord blood for treating spinal cord injuries in dogs. J. Vet. Med. Sci. 74(12):1617-1630. 
Santos R.M., Magrisso A.B., Terraciano P.B. \& Gross L.S. 2013. Diferenciação de células-tronco mesenquimais de tecido adiposo de camundongos gfp + . 33a semana cientifica do hospital de clínicas de Porto Alegre. Revta HCPA 33(Supl.):11.

Sato M., Storb R., Loretz C., Stone D., Mielcarek M., Sale G.E., Rezvani A.R. \& Graves S.S. 2013. Inducible costimulator (ICOS) up-regulation on activated $\mathrm{T}$ cells in chronic graft-versus-host disease after dog leukocyte antigen-nonidentical hematopoietic cell transplantation: a potential therapeutic target. Transplantation 96(1):34-41.

Shivdasanl R.A., Mayer E. \& Orkin S.H. 1995. Absence of blood formation in mice lacking the T-cell leukaemia onco protein tal-1/SCL. Nature 373:432-434

Silveira P.A. 2000. Hematopoiese: alguns aspectos. J. Bras. Nefrol. 22(Supl.5):5-6.

Stolfi J.L., Pai C.C. \& Murphy W.J. 2016. Preclinical modeling of hematopoietic stem cell transplantation - advantages and limitations. FEBS J. 283(9):1595-606.

Suter S.E., Gouthro T.A., McSweeney P.A., Nash R.A., Haskins M.E., Felsburg P.J. \& Henthorn P.S. 2004. Isolation and characterization of pediatric canine bone marrow CD34+ cells. Vet. Immun. Immunopathol. 101: 31-47.

Suter S.E., Hamilton M.J., Sullivan E.W. \& Venkataraman G.M. 2015. Allogeneic hematopoietic cell transplantation in a dog with acute large granular lymphocytic leukemia. J. Am. Vet. Med. Assoc. 246(9):994947.

Tharasanit T., Phuticanit N., Wangdee C., Soontornvipart K., Tantrajak S., Kaewamatawong T., Suwimonteerabutr J., Supaphol P. \& Techakumphu M. 2011. Differentiation potentials of canine bone marrow mesenchymal stem cells. J. Vet. Med. 41(1):79-86.

Thomas E.D., Collins J.A., Hernan Jr E.C. \& Ferrebee J.W. 1962. Marrow transplantations in lethally irradiated dogs given methotrexate. Blood 19:217-28.

Togonoli K.G., Olsson D.C., Martins D.B., Santos Junior E.B., Salbego F.Z., Oliveira G.K., Braga F.V.A., Raiser A.G., Dezengrini R., Cruz F.S.F., Castro M.B., Rosa M.C., Carregaro A.B. \& Pippi N.L. 2009. Bone marrow mononuclear cells autotransplant in experimental corneal ulcer in dogs. Ciência Rural 39(1):148-155.

Vrecenak J.D., Pearson E.G., Santore M.T., Todorow C.A., Li H., Radu A., Bhatti T., Peranteau W.H., Johnson M.P. \& Flake A.W. 2014. Stable long-term mixed chimerism achieved in a canine model of allogeneic in utero hematopoietic cell transplantation. Blood 124(12):1987-95.

Zorn J., Schwamberger S., Panzer W., Adler H. \& Kolb H.J. 2011. Transplantation of CD6-depleted peripheral blood stem cells after DLA-haploidentical bone marrow transplantation contributes to engraftment and tolerance in a preclinicalmodel of stem cell transplantation. Vet. Immun. Immunopathol. 144(2):27-35. 